Volume 29

Issue 3 September

Article 6

September 1993

\title{
Telemachus and the Last Hero Song
}

Richard P. Martin

Follow this and additional works at: https://digitalcommons.colby.edu/cq

\section{Recommended Citation}

Colby Quarterly, Volume 29, no.3, September 1993, p.222-240

This Article is brought to you for free and open access by Digital Commons @ Colby. It has been accepted for inclusion in Colby Quarterly by an authorized editor of Digital Commons @ Colby. 


\title{
Telemachus and the Last Hero Song
}

\author{
by RICHARD P. MARTIN
}

\begin{abstract}
In the Odyssey, it is evident that
Telemachus, the exemplary son, will never equal his cruel, restless father. Nor will the astronauts, for all their lonely voyaging, stir us as deeply as Dillinger. -Paul Zweig, The Adventurer ${ }^{1}$
\end{abstract}

\begin{abstract}
T F EPICS ARE PRODUCTS of an elegiac urge for touching heroic ages past, the Odyssey, that greatest nostalgic poem, cannot but be already a metatext. ${ }^{2}$ The protagonist's desire to return to his past, to all that Ithaca and Penelope represent, is counterpointed throughout the poem by a second desire, on the part of Telemachus and other audiences, to hear the past, a desire enacted, challenged, and, once in a while, satisfied, in scenes of elaborate design, from Phemius' song of the Achaean nostoi (Od. 1.325-59) to the stories of Nestor, Menelaus, and Helen in Books 3 and 4, reaching a climax in Odysseus' narrative in Book 11 about his encounters among the dead, and an anticlimax in his hurried rehash of his adventures for Penelope (23. 306-43). ${ }^{3}$ By extension, this desire is ours as hearers of the Odyssey. To some degree, this latter desire can be identified with an audience's needs and expectations: a poem performed without divagations would be abrupt and inartistic, completely contrary to the expansive style at which both Homer and the performers within his compositions are masters. ${ }^{4} \mathrm{~A}$ poem about Odysseus, polutropos, is even more so in its essence diverse. Part of the fascination of the Odyssey comes from the tension between narratives performed within the poem and the course of the external plot; sometimes they conflict openly, as when Odysseus' apologoi on Scheria delay his homecoming. Of course, only a perverse sort of nostalgia for a "primitive narrative" stripped of digressions would want to do away with the apologoi of Books 9-12.5 A more subtle attack, however, on the texture and structure of the Odyssey is still carried

1. Zweig (1974) 46.

2 . This self-reflexivity of the poem enables it to blend easily with early Greek philosophical thought: see Lachterman (1990).

3. For outstanding treatments of the depiction of such narratives and audiences, especially in Book 11 , see the two recent articles by Doherty (1992 \& 1991). Wyatt (1989) sees in the expansions here a reflection of actual audience-poet interactions.

4. I deal with this shared style at length in Martin (1989).

5. This perversity in Odyssey studies is brilliantly analyzed by Todorov (1977) 53-65.
\end{abstract}


out in some quarters these days, prompted apparently by the quest for the "primitive," and it is this which the present paper attempts to counter, by taking seriously the metapoetic meanings of one figure in the poem, Telemachus.

The first four books of the Odyssey, the so-called "Telemacheia," provide the clearest example of the remarkably fractured contemporary critical reading of Homeric poetry. On one side, classicists such as Reucher and van Thiel continue to produce readings in which these introductory episodes are treated as additional, extraneous, marked by a second hand, that of a postulated "T-poet" who had different goals than the "O-poet," the master credited with what they call the main body of the poem, the story of Odysseus. ${ }^{6}$ On the other side, scholars like Pucci, Peradotto, Katz, and Murnaghan approach the Odyssey as a unity, and work from an informed literary-critical perspective, but focus their attention on smaller problems of character or theme and so avoid two issues: why the poem is shaped, overall, in the way it is, and how the poem relates to the world of oral composition-in-performance. ${ }^{7}$ In other words, these modern "Unitarians" (to use the terms of an older Homeric debate), while managing to escape the pitfalls of "Analyst" dissection of Homer, in embracing attractive deconstructive reading and modernist thematics have nevertheless neglected or misunderstood the most important body of critical work on Homer in this century, the contextbased approach of those who discovered in Homeric poetry the product of a living, oral folk art.

A study of the Odyssey starting from the figure of Telemachus might wed the insights of both sides in the critical schism by moving discussion onto a different level, that of folk epic performance and the social situations it entails. But beginning with a figure, rather than a theme, involves the critic in one difficulty right away: there is probably no more contested area in literary study than characterization. Recent trends in explicating literature, and especially narrative, have not managed to do justice to this crucial part of the tale-teller's art. Theory has not been able to help the readers of Homer go beyond our instant and strong impression that character construction in the Homeric poems is brilliant, subtle and cunning. What is more, all too often sophisticated analysis of narrative actually has impeded any appreciation of characterization, whether in epic poetry or elsewhere. As Robert Alter, the comparatist and critic of Hebrew literature, wrote recently, "the narratologists have scarcely any critical vocabulary for encompassing the mimetic dimension of character." 8

We can trace this state of affairs fairly well. The Russian formalists of the 1920 s and 1930s, with their total emphasis on plot as the determinant of

6. Reucher (1989) on which see my review Martin (1992); van Thiel (1988) uses less personalized notions of Früh-and Spätodysseen. For the history of the Analytic treatment of the Telemachy, see Heubeck (1974) 87-113. Patzer (1991) offers a concise critique of Analyst procedure regarding the Telemachy. S. West in Heubeck et al. (1988) vol. I, 53-54 appreciates the importance of the Telemachy for the poem as a whole, but still is tempted to think this section originated as an independent narrative.

7. Unless otherwise noted, the citation of the authors' names in this paper will refer to the following books by them: J. Peradotto, Man in the Middle Voice (1990); P. Pucci Odysseus Polutropos: Intertextual Readings in the Odyssey and the Iliad (1987); M. Katz Penelope's Renown: Meaning and Indeterminacy in the Odyssey (1991); S. Murnaghan Disguise and Recognition in the Odyssey (1987a).

8. Alter (1989) 51 . 
character, tended to reduce characterization to a question of function: the model underlying their work is most explicit in Vladimir Propp's well-known Morphology of the Folktale, published in 1928, in which he illustrates how a small set of functions and agents from magic helpers to villains can generate a large corpus of Russian wonder tales. ${ }^{9}$ Later structuralists of the 1960 s and 1970 s, including Barthes, Greimas, and Tzvetan Todorov, built onto Formalist narratology. 10 While Todorov acknowledges that there are novels constructed around character (those of Henry James, for example) as well as around plot, he devotes more interest to the techniques and theory behind the latter category. ${ }^{11}$ More recently, social and political commitments have turned the focus of contemporary literary theory to popular, noncanonical, and often anonymous works, in other words, precisely those fictions that privilege structuralist interpretation. Subtle characterization is not what audiences most value in television soap opera or popular fiction; of more interest is the genre's virtuosic manipulation of pure plot elements. Finally, nonliterary "character," the notion that we can identify a subsisting, consistent set of behaviors all deriving from some inner force, sounds too transcendental for our grittier fin de siècle.

It is significant for Homeric studies that a state-of-the-art book like Marylin Katz's Penelope's Renown problematizes the very notion of character, reading into the figure of Penelope the radical indeterminacy of the poem's plot possibilities. ${ }^{12}$ For this strategy, although deconstructive in nature rather than structuralist, still privileges event over person, plot over character, by viewing the latter as a reflex of the former. ${ }^{13}$ It represents a valuable mode of investigation but leaves us, partly by its very sophistication regarding the ontological, with the more practical critical problem of how figures in the Odyssey are represented in this sort of poetry to begin with: how we perceive "character" and, more to the point, how an audience for a performance, rather than readers of a text, accumulate knowledge of the actors within the dramatic narrative. These questions require one to grapple with oral poetics, the possibilities of which are still largely undeveloped among classicists.

A decade ago Jasper Griffin found it necessary to start from scratch when he tried to talk about characterization in the epics: "I hope that it will prove possible," he wrote, "to establish some general points about the existence in the poems of characterization, and to see how it is used, rather differently in the two epics, towards the same goals." 14 Griffin must resort to such tentative phrasing

9. Propp (1958). On his place in Formalist theory, see Birch (1989) 124-25 and Steiner (1984) 80-95.

10. The lines of development are sketched by Culler (1975) 230-38.

11. Todorov (1977) 66-79.

12. Katz 3-19 is most explicit about this procedure, which, as she acknowledges, is also prominent in the Odyssey books by Pucci and Peradotto. Cf. Peradotto 153-54 who elaborates on the viewpoints of Barthes and Bremond regarding the instability of the notion of "character."

13. Cf. Peradotto 122-23 who rightly criticizes "standards of verisimilitude derived from the nineteenth-century novel" but explains apparent inconsistencies in Odysseus' character as deriving from "functional goals to be achieved in the ensuing narrative" (122 n.1), thus seeming to introduce an equally rigid and time-bound standard of plot efficiency.

14. Griffin (1980) 50. In his chapter on characterization he sets himself the modest goals of showing that Homeric characters can differ from one another, have implicit intentions, and be complex (cf. p.52). 
because he has read the history of criticism on Homeric characters, from Wilamowitz to Kirk, a history marked by two trends: the perfection of Analyst techniques in the last quarter of the 19th century and the development of oralformulaic techniques for reading Homer in the mid-20th century. For the Analysts, including Wilamowitz, there could never be consistent characterization in the epics because the poems themselves were patched together by rhapsodes, interpolators, Redaktors and Bearbeiters, who willfully transferred words appropriate to one scene-or worse, one character - to another. The work of one of the last of the old-time Analysts, Denys Page, overlaps the second trend, the oral-formulaic. Page, in his Homeric Odyssey, can at least explain the alleged mistakes on which earlier Analysts had fastened. The "muddled" instructions of Athena to Telemachus, in Book 1, Page attributes to an oral performer, either a creative poet or an oral reciter, who allegedly mixed things up, transferring to Athena language that belongs properly to the suitors. In Page's solution the poet here becomes the careless botcher, a position formerly reserved for the Analysts' obtuse editors. 15

The second trend that affected studies of Homeric character should not be attributed solely, or even mainly, to Milman Parry, although his work doubtless provided the impetus. In his groundbreaking thesis on the traditional epithet, Milman Parry defined the formula as "an expression regularly used, under the same metrical conditions, to express an essential idea." 16 This way of looking at the formula was coupled, in Parry's analysis, with the well-known demonstration of the economy and extension of the formulaic systems: the notion that there existed one, but generally only one, formulaic phrase for each grammatical case of a given name and epithet. He concluded that such systematicity meant no one descriptive adjective was invented for the individual passages in which we might find it in the poems of Homer. Epithets were a reflex of the necessity for creating compositions in performance. ${ }^{17}$ Parry's thesis, it can be seen in retrospect, traces the same theoretical path, on the level of diction, that the Russian Formalists trod in dealing with character. Like them, Parry was not necessarily against the view that any one element in a composition had deeper meaning. He was merely concerned to show that there was a functional basis for the appearance of epithets. Parry himself did not extend his theory as far as the problem of characterization in Homer. He did, however, recognize so-called "isometric" formulas. For example, Odysseus is described twice as polutropos, "having many turnings." This happens in the first line of the poem, and again at 10.330. But Parry notes there existed another epithet, equivalent in metre, namely diiphilos, "dear to Zeus," which the poet could have used for Odysseus at the two places where he chose polutropos instead. Thus, Parry leaves open the possibility that Homer can employ "particularized" epithets. ${ }^{18}$ We would expect that these

16. Parry (1971 [1-190]; hereafter $M H V) 13$.

17. A review of the thesis and subsequent alterations can be found in Martin (1989) 149-52.

18. $M H V 153-58$. 
particularized epithets, few as they might be, would form the basis of an examination of Odysseus' character. Parry does not undertake such an exercise. Yet he is not against it: the proper sphere for investigating character in this type of poetry simply seemed to lie outside the system he had discovered. He claims that "we learn the characters of men and women in the Iliad and the Odyssey not from epithet but from what they do and from what they say."19

Unfortunately, Parry's quite elegant theory, with its tremendous value for arguing that Homeric poetry was meant originally for oral performance, led in the next generation after Parry to a severely reductionist reading of Homeric poetry. ${ }^{20}$ Again, Denys Page was one of the more authoritative and articulate proponents of what we might call the determinist view of poetic composition. Page in his 1959 book on the Iliad wrote that Homer used ready-made phrases "extending in length from a word or two to several complete lines, already adapted to the metre and either already adapted or instantly adaptable to the limited range of ideas which the subject matter of the Greek Epic may require him to express." 21 It does not take much reflection to realize that such a squint-eyed view of Homer blocks out any possibility that the poet can create rich, resonant characters, indeed, can create anything aesthetically satisfying at all. In this view, either there are unlimited formulas - many of which we cannot even identify as such, on the basis of the texts we have-or Homer is bound by his art to sketch two-dimensional figures instead of rounded characters.

Since the late 1950s, Homerists, when they have chosen to focus on character at all, have generally done so by skirting the issue of formulaic composition. Oral theory created an embarrassing dilemma. One knew at first reading that Homeric poetry contained three-dimensional, deeply felt characters. At the same time, the poet's formulaic technique - at least as far as it had been described - should not have resulted in anything at all like good characterization. The more literary Homerists tended to finesse the problem: Cedric Whitman, for instance, wanted very much to believe both Parry's thesis and his own acute sensibility. In a chapter of his 1958 book entitled "Homeric Character and the Tradition," Whitman starts with the observation that "Homeric epic differs radically...even from the most sophisticated evolvements of oral poetry found anywhere." 22 When he notices slightly changed repetition of motifs, or embellishments, in arming scenes or aristeiai, Whitman is careful to suggest that such characterizing touches are the mark of a brilliant creative poet moving beyond the formulaic tradition. Homer, in this view, turned out to be an exception, the kind of poet one could just barely imagine within an oral tradition: "With singleness of vision and real mastery of the rudiments, a poet might so dispose and deploy his material that the generalized motifs, crystallized phrases, and traditional imagery fall into contextual groupings of great specific signficance." 23 Thus, Whitman accounted

19. $M H V 152$.

20. For overviews of this process, see Foley (1985); Lord (1986); and the annotated bibliography by Edwards (1986).

21. Page (1963) 222

22. Whitman (1958) 154.

23. Whitman (1958) 180. 
for both greatness and technique by saying, in effect, that Homer outgrew his own art. Jasper Griffin, in Homer on Life and Death, also manages to provide some examples from the Iliad of characterization by means of slight change in a type-scene or by verbal repetitions. ${ }^{24}$ But he, too, refuses to place the fact of characterization within the Parry model of oral-formulaic composition. In fact, he prefaces the book by saying that he has serious doubts about the utility of much oral-formulaic analysis for interpretation of the poems. We are left with a finely written belle-lettristic appreciation and Griffin's commitment to taste and sense as the standard for judging our literary impressions. ${ }^{25}$ If all this is a helpful corrective to the abuses of a mechanistic approach to literature, it still provides no usable understanding of technique, or any explication that would aim for a much needed "unified field" theory of Homeric poetics.

The Odyssey itself begins with an extended focus on Telemachus; this by itself justifies an investigation of his character, which, in turn, requires one to face the practical poetic problem of character construction. Only in this way can we understand the hero's son from the inside out, as it were, on the level of the poet's own technique. In what follows I shall outline several ways of employing the tools of oral-formulaic analysis in the study of characterization. Clearly, there is material enough for a book-length study (on which I am currently engaged). But the brief examination of 'Telemachus' characterization in Book One will suffice to show that we can consider Homer a master poet without abandoning our belief that he works within a traditional performance medium. Furthermore, it will lead us to reconsider the shape and intent of the entire Odyssey.

First, a word about method. The more we learn about actual oral poetries, from Central Asian to Arabic and African to South American Indian, the more obvious it becomes that the traditional audience of an oral performance, the "native speakers," as it were, of the poetry, have, all of them, the mental equivalent of a CD-Rom player full of phrases and scenes. Reading Homer with the aid of a computerized lexical searching program enables one finally to replicate the average experience of the audience Homer had in mind. Modern hearers of a traditional epic in cultures where the song making survives are observed to comment appreciatively on the smallest verbal changes, not in the way a threeyear-old demands the exact words of a bedtime text, but with a full knowledge of the dozens of ways the teller could have spun out a line at a given point in the narrative. In a living oral tradition, people are exposed to verbal art constantly, not just on specific entertainment occasions, which can happen every night in certain seasons. When they work, eat, drink, and do other social small-group activities, myth, song, and saying are always woven into their talk. Consequently, it is not inaccurate to describe them as bilingual, fluent in their natural language but also in the Kunstsprache of their local verbal art forms. ${ }^{26}$ In other words, when we compare every use of every word in Homer with every other use,

24. Griffin (1980) 53-56.

25. Griffin (1980) xiii-xiv.

26. A wealth of examples may be found in the following sample of excellent studies: Blackburn et al. (1989); Lutgendorf (1991); Mills (1990); Chadwick and Zhirmunsky (1969); Basso, (1985); Moyle (1990). 
we are doing what the listener to an oral poem in a strong native tradition does naturally. I would go further and say that the full "meaning," and the full enjoyment, of traditional poetry come only when one has heard it all before a hundred times, in a hundred different versions. Unfortunately, we are left with only one version of the Odyssey, but this still means: to read Homer is to have read Homer. ${ }^{27}$ In reading the Odyssey, we must first identify a range of "meaning" for both phrases and type-scenes, then use the dictionary of this poetics to interpret the individual items as they occur chronologically in the narrative of the poem. The method may seem counter-intuitive when an argument for the meaning of a scene in Book 1 is based on a repetition of a few phrases in, say, Books 20 and 24. But in fact this is precisely the point where oral poetics must differ from standard literary criticism. The reader of a modern novel, for instance Joseph Conrad's Nostromo, only gradually learns, page by page, in temporal order, just how ironic are certain epithets applied to the stevedore or the English mine owner. That is because each novel creates its own language within a genre that makes a demand, even by its title, for something completely new. It is true that Telemachus, in Book One of the Odyssey, tells off his mother by pointing out that listeners always are delighted by the newest song-in this case the return of the Greeks from Troy (1.351-52). But his remark is ironic in several ways, as I shall show later. Homeric epic does not work like a novel; the "character" of any given person is not constructed anew in each performance, but neither is it a set value known to all in the audience. Thanks to its traditionality and flexibility - the two aspects seen by Parry in the formulaic systemHomeric epic can accomplish characterizing effects that prose fiction cannot bring about.

The characterization of Telemachus occurs in at least four different modes in Book One, all of which function specifically by means of formulaic style and oral performance. Briefly, they are: first, the epithets with which the poet describes him; second, the way the poet frames Telemachus' speeches using formulaic language; third, Telemachus' stylized rhetorical strategies within the nine speeches the poet allots him in the book; and fourth, the way in which the poet focalizes the Odyssey narrative through Telemachus.

The first mode, the epithet system, brings us back of course to the nub of the problem of characterization within oral-formulaic poetry. Since Milman Parry's demonstration that the epithet is economically useful, a few literary critics have interpreted his conclusions to mean that epithets are semantically empty. Some Homerists have felt compelled to defend the appropriateness to context, and the resonance, of such famous epithets as grain-bearing earth (phusizoos aia), used by Homer at Iliad 3.243 to describe the earth that covers Helen's brothers, the Dioscuri, whom she pathetically thinks are still alive. ${ }^{28}$ This is not really a counter-argument to Parry's position. In such cases, there is nothing to prevent

27. This is one of the ways in which an "oral poetics"-dismissed by Griffin (1980)-differs significantly from methods applied to purely written texts. On the differences for our interpretive strategies, see Russo (1987).

28 . This is one of the prime examples among many used to this point by Vivante (1982). 
our saying that the epithet is both metrically functional and poetically beautiful. No one, to my knowledge, has yet tried to argue that every time each epithet for a hero is used in Homer it is somehow just as apt, in its immediate context, as phusizoos aia in Iliad 3. And yet there is evidence that the consistent use of certain epithets for certain heroes and not others is meaningful within the formulaic system. William Whallon in 1969, Norman Austin in 1975, and most recently Richard Sacks in his 1987 study of epithets for Hector show this. ${ }^{29}$ Sacks can demonstrate that Hector's epithets phaidimos "shining" and androphonos "man-killing" are indeed deeply significant in terms of the theme of the Iliad, but not necessarily significant at a narrative level in terms of the immediate scene in which they occur. With Telemachus in Book One we can go a step further. Not only is the use of epithets with his name significant on a deeper thematic level: the poet's use of epithet is also sensitive to the context of a particular scene.

Consider the first time we see Telemachus, at $O d .1$.114. Athena in the guise of Mentes has just arrived at the palace in Ithaca. Telemachus sees her first. The line runs:

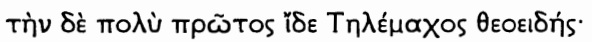

$$
\begin{aligned}
& \text { Telemachus, in appearance like a god, saw her first. }
\end{aligned}
$$

A lexical search reveals that the polu prôtos phrase "by far the first" is itself a formula used a half-dozen times in the Iliad in scenes where one warrrior either volunteers first for a test of skill or wounds his enemy first (Il. 7.162, 8.256, $14.442,23.288$, etc.). Within the Odyssey, lines beginning "ton Itên de polu prôt_-_" occur two other times, both in Book 17, which we will turn to examine later. But let us pause over the epithet for a while. Theoeidês, "in appearance like a god," at first glance occurs here because the predicate phrase, from tên to ide in the line, leaves a certain metrical slot for the subject phrase. It happens that of the four noun-epithet formulas attested for Telemachus in the nominative case, only this one will fit this metrical slot: it is an economic system, in other words. ${ }^{30}$ The main weakness of this sort of explanation has been exposed by Austin, who pointed out that most of the time the name Telemachus, when we consider all grammatical cases, does not even have an epithet: the poet could have made a line here without an epithet at all. ${ }^{31}$ More recently David Shive has gone a step further to show exactly what sorts of other lines Homer could have made up without using certain epithets when he did. ${ }^{32}$ Such arguments chivalrously defend the freedom of the poet (although it does not follow that we must agree with Shive's contention that Homer, thus liberated, therefore has to be a literate composer). But what is the payoff for our reading of an individual scene such as this?

29. Whallon (1969); Austin (1975) 11-80; Sacks (1987).

30. The other epithets for this case are hierê is; pepnumenos; and hêrôs: see lists in Austin (1975) 55.

31. Austin (1975) 58-61.

32. Shive (1987). 
Once we admit that the epithet use is not merely mechanistic, three possibilities for interpretation arise:

1) That Homer even used an epithet for Telemachus here, when we first see him, signals that the scene immediately following is important for our understanding of Telemachus' character. In this regard, the epithet is like a single musical note sounded at the start of a composition.

2) The epithet theoeidês, "like a god in appearance," has a deeper significance in terms of its connection with an essential theme of the Odyssey, namely the obscure dividing line between humans and mortals. 33

3) The epithet is significant in contrast to any of the other three epithets for Telemachus which Homer might have used had he shaped the line a bit differently. In other words, the epithet has as great a role, or greater, in determining the line's shape as does the verbal phrase. Theoeidês is used because it best fits the narrative moment at $O d .1 .114$.

An explanation of these three points will show that they are not mutually exclusive. All the effects mentioned can operate at once. We might get a better angle of vision on the first phenomenon by first looking at archaic poetry in a related poetic tradition, that of Old Irish. A number of praise poems survive in Old Irish, written to commemorate local warrior kings by their tribal poets in the 6th century A.D. and later ${ }^{34}$ One of these archaic alliterative poems purports to praise a mythical king, Móen:

1. Móin óin, ó ba nóid, ní bu nós ardríg,
oirt ríga, rout án, aue Luirc Labraid.

4. Gríb indrid iath n-anéoil aue Luirc Lóiguiri arddu dóinib acht nóibrí níme.

5. ór ós gréin gelmair gabais for dóine sceo déib, día óin as Móin macc Aini óinríg.

Móen the only one, since he was a childnot as a high king - slew kings, a splendid throw, Labraid grandson of Lorc.

A griffin who overran unknown countries was the grandson of Lóegaire Lorc,

Higher than all men except the holy king of heaven.

Gold brighter than the sun, he became lord of men and gods, the one god is Móen son of Ane the only king. ${ }^{35}$

It is clear that the basic pattern of such praise poetry is to make predications about the subject. This is done in old Indo-European syntactical style by nominal sentences in which the copula "be" is not expressed, as in the third line printed here, which reads literally "A griffin who overran countries unknown- the

33. On this Homeric theme, see especially Nagy (1979) 151-73 and Clay (1983) 159-83.

34. On this poetry see Williams and Ford (1992) 40-44.

35. Translation in Dillon (1969) 18. Text from Meyer (1913) 10-11. Prof. Donnchadh 6 Corráin points out to me that the phraseology of the poem indicates it is probably an archaizing composition by a Christian poet. The stylistic point still stands, however. 
grandson of Lóegaire Lorc." 36 Other such praise poems have even less narrative. They resemble strings of predicates. Consider this one on a trio of heroes called the three Fothads. The proper names come first in each clause in the first couplet, last in the second:

\author{
Find a poet; Russ red-haired; \\ Fergus fiery; lord of the sea. \\ A princely champion Nuadu Necht; \\ a bright poet phrase are the three Fothads. ${ }^{37}$
}

One could argue from verse like this and from Sanskrit parallels that such praise poetry is in fact the ultimate ancestor of epic diction. Gregory Nagy has demonstrated a related point most fully in his book Pindar's Homer, which shows how the very basis of Homeric verse, the unique hexameter meter, could have arisen from shorter meters as found in lyric poetry of archaic IndoEuropean languages. 38 If we extend the argument now to the structure of the formula as well as the meter in Homer, we can say that such phrases as Têlemakhos theoeidês could have started as complete sentences forming a full eight-syllable verse in an archaic praise poem. The phrase, as a nominal sentence, would mean "Telemachos is in appearance like a god." Similar sentences really do survive in Greek poetry, specifically in a praise context: for instance in

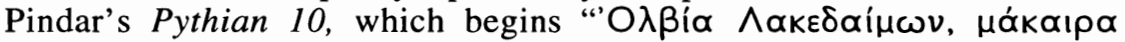

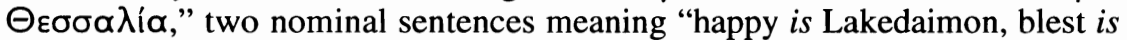
Thessaly." This is to say, then, that Homeric epic fills out the story implicit in each noun-epithet formula. Epic treats these units as noun phrases, rather than complete sentences, and epic provides each with another verb, as here, so that the adjective becomes attributive rather than predicative: "Telemachus, in appearance like a god, first by far saw him." What must be stressed is that the very use of a name with an epithet in Homer conserves the poetic function of the old nominal sentence, if not the syntactic function. Such phrases occur in the narrative at key moments. Notice that this is contrary to the view often put forward by some readers of Parry, that epithets occur as padding, somehow filling out the line at the unimportant moment when the harried oral poet just wants to get through his sentence and onto the next one and does not pause to think up a novel adjective but simply throws in one that he knows will fit. Turning that view on its head, we see that here the key moment is the introduction of a character we have not encountered before in this performance. Theoeidês then functions like the applause from the audience when a well-known actor walks on stage, even if it is in a new role on opening night. Homer and his long praise poetry tradition is making a statement about Telemachus.

What is the statement? Here we can turn to my second observation. The content of the epithet does not necessarily relate to the content of the immediate context. But it does tie in to a very important underlying theme of both the Iliad

36. On this syntactic style see Benveniste (1966).

37. Meyer (1913) 14.

38. Nagy (1990b), esp. 439-64. The argument is made at greater length, with Sanskrit dictional comparanda, in Nagy (1974). 
and the Odyssey, namely the distinction between gods and mortals. The Iliad offers us scenarios in which heroes overstep the limit, fighting even against the gods. And the Iliad, as well, in the character of Paris, also called Alexandros, examines the gap between appearance and reality, opening up the possibility that one can have an astoundingly good appearance and still be a coward. Hector berates his brother Paris in Book 3 (Il. 3.39-45):

\footnotetext{
Evil-Paris (Duspari ), best in appearance, mad for women, beguiler:

You should have stayed unborn and died unmarried.

I'd prefer that; it would be a lot better

than to be a mockery like this and despicable (hupopsion).

No doubt the long-haired Achaeans are cackling,

saying you're the most conspicuous fighter because you've got a good appearance, but there's no force in your guts and not a bit of strength.
}

Hector uses the noun eidos, "appearance," three times in this one speech, all to the effect that it is not any guarantee of martial craft. In fact throughout the Iliad, mentioning another's eidos can be a way of implying that the warrior in question has not got the mettle to survive. In this scene of Book 3, it is thus ironic that the poet Homer, within narrative, consistently denotes Paris with the phrase Alexandros theoeidês, as in the line just before the speech I have translated (Il. 3.37). The Odyssey, too, dwells on the theme of appearance versus real ability in several places. In a way, the entire action of the poem is predicated on the ability to disguise one's eidos as Odysseus is so successful at doing. ${ }^{39}$ Ironically, it is Odysseus in disguise who sermonizes on "appearances" after being mocked during the games of the Phaeacians in (Od. 8.167-77). After instructing Euryalus about the diversity of the gods' gifts, he notes (apparently in self-reference):

One man is of less account in appearance (eidos)

But the god puts a crowning shape on his words,

And the people look on him and take delight.

In the dramatic situation of this passage, having a good eidos implies that one is neither a good speaker nor, in fact, very bright. It is significant that the young man Euryalus, who has athletic ability but no rhetorical graces, is the object of Odysseus' admonishing words..$^{40}$ In the course of the Phaeacian episode, we see the young man learn. By the end of Book 8 he has the wit and poise to offer Odysseus a sword and an apology. This process of education is precisely what happens to Telemachus in the course of the Odyssey as a whole, as many critics have remarked. ${ }^{41} \mathrm{My}$ point is that the use of the formula theoeidês marks out Homer's handling of this traditional theme, which we can call "the hero grows up." When an audience keyed into the traditional formulaic system first hears Telemachus described as "having the appearance of a god," it receives a package of thematic messages, as it were, a box of potential narrative directions. This character, the son of Odysseus, could turn out to be like Paris, Alexandros

39. Murnaghan (1987a) 3-55.

40. See my analysis in Martin (1984) 29-48.

41. See, with further bibliography, Tracy (1990) 3-26 and J. H. Finley (1978). 
theoeidês, all Schein and no Sein, an indolent golden boy who relies on looks to get by. Or he could be like Euryalus--arrogant but essentially educable. In fact, each of these two thematic alternatives is displayed in the course of the Odyssey. The adjective theoeidês is used three times to describe one or other of the pair of chief suitors on Ithaca, the arrogant young men Eurymachus and Antinoos (Od. $4.628,21.186,21.277$ ). They are the Paris types, whose behavior clashes with that of Telemachus. The repentant type is also described, in the figure of the seer Theoklymenos, to whom the epithet is applied five times, and whose very name "god-hearing" fits the meaning of theoeidês. When this young man, a fugitive because he slew a kinsman, encounters Telemachus (Od. 15.256-81), we see an important stage in the growth of the latter: without questioning, he takes in the outlaw, thus showing how he has assimilated the code of guest-friendshipprecisely the skill which the suitors conspicuously failed to learn. The meeting of characters who are described with the epithet theoeidês therefore encapsulates a key theme in the poem as it also characterizes Telemachus.

To sum up my first two observations on characterizing by epithets: the very occurence of an epithet signals the presence of an important theme when Telemachus first comes into view. The theme, in turn, comes to be more explicitly examined in the course of the poem, before the action returns to Ithaca. At that point, Homer's poetic art has a way of wrapping up the theme by a ring composition. When we see Telemachus again in the hall in Book 17, the poet describes him with a line identical to this line in Book 1, except for the initial object pronoun (17.328). The line refers to Telemachus' noticing Eumaeus before anyone else does. He nods to the swineherd and arranges a private conversation (17.330-34). Repetition here works in a slightly different way than does the recurrent epithet. An audience gets more meaning from the second occurence of the line because the audience recalls the first use and its context. By Book 17 Telemachus has matured, and the repeated line enables us to juxtapose this scene with the earlier one. In Book 1, when Telemachus receives Mentes, who is actually the disguised Athena, he leaps nervously to the door; after seating his guest, he bombards him with a breathless account of his own sorry state before even asking where Mentes comes from (1.158-71). By contrast, Telemachus in Book 17 does not rush to talk; he barely talks at all; a single nod accomplishes all he wants. When Telemachus does speak, it is only to utter a laconic threeliner: "Give the stranger this food; tell him to beg from all the suitors. For a man in need, a sense of shame's no good" (17.345-47). The characterization of Telemachus thus works through a process of careful differentiation. The formulaic element—whether the word theoeides or a repeated line-provides the core that enables us to think of Telemachus as a consistent character at all. On the other hand, the repetition in different contexts of the formulaic elements lets us construct a three-dimensional picture of the hero. He is not, after all, just godlike in appearance; he is a person who notices things, who gets the point, before all others, polu protôs.

Does it make a difference that Telemachus is called theoeidês when we first see him in the Odyssey, rather than one of his other epithets in the nominative: 
hierê is, pepnumenos, or hêrôs? I think it does, precisely because we first see him. This is my third observation on the epithet. His three other epithets all assert some knowledge on the part of the poet of Telemachus' inner state: his "holy strength" or "prudence" or that he is a "hero." But when we the audience first see Telemachus, we don't yet know what he is like. Therefore, in this all-important curtain-raising epithet, Homer takes the part of his audience. He refers to Telemachus' appearance only. When Telemachus speaks later in Book 1, he can be called "prudent" (pepnumenos), because at that point we hear as much from his own words. ${ }^{42}$ Finally, there is the clever etymological play in this single line that introduces Telemachus. The young man saw (ide) Mentes: we see him precisely at the moment when he sees someone else. And to add to this, we see that he has a certain look (theo-eid-ês-built on the root *wid "to see"). To complete this tour de force introduction, Homer tells us that Telemachus, until he catches sight of the visitor, had been viewing mentally (ossomenos) another prospect: that his father would return and scatter the suitors to the winds. It is significant that we cannot see Telemachus without instantly hearing of his father. Part of the interest of the rest of the plot will come from seeing how far Telemachus can distinguish himself from his father; the process has not yet started when we first see him. Such self-conscious mirroring, the reflecting of our gaze in that of the young hero, is hardly an accident of a mechanistic application of formulas. Instead, this initial scene works as an elegant piece of exposition and intentional characterization. Possible confirmation that Homer here builds up a motif complex of seeing well/looking good comes from Book 17 again. Just before the line which repeats this introdutory line (17.328) comes the most famous and pathetic scene of gazing in the poem, when poor flea-bitten Argos notices the master who left him twenty years ago, strains his ears, wags his tail, and dies (17. 301-27). The Homer who so ironically named this dog "Flash" (Argos) could well have played again on the fascination with sight and appearances generated out of the single epithet theoeidês.

The epithet system's importance in characterization has justified the effort thus far to show just how much we can use it. With the other three elements of characterization in which oral-formulaic technique plays a part, I will more briefly show how they build up the specific theme of Telemachus' growth into authority. I have already alluded to the second mode of the technique: the way in which Homer frames speeches. The epithet system comes into play here, since the adjective pepnumenos, as Norman Austin recognized, only occurs when the poet uses it to say "Telemachus spoke" in some form. ${ }^{43}$ Beyond this, however, there is another speech-framing device which characterizes the hero even more explicitly. This is Homer's employment of the word muthos. I have come to the definition of this word as "authoritative utterance" after close reading of the formulaic expressions in which the word appears in Homer. To summarize the

42. Austin (1975 ) 75-78 well draws out the complimentary associations of this epithet but does not notice the narrative sequencing of epithet usage.

43. Austin (1975) 74 . 
system, which I outline fully in The Language of Heroes: of the two main words for speech in Homer, muthos is the marked term and epos the unmarked. Muthos refers to important speeches that accomplish something, or to performative utterances. Epos can be used for any utterance. ${ }^{44}$ In other words, by naming some speech act muthos Homer foregrounds the particular words. In terms of this system it is highly significant that Telemachus is shown to exercise with increasing authority the type of speech called muthos. The first example comes in Book 1. Towards the end of the scene in the hall, Telemachus' mother descends from her quarters to tell the bard to stop singing that sad song about the return of the Achaeans from Troy. Telemachus, somewhat intemperately it may seem, comes to the defense of Phemius the poet with an apology worthy of any beleagured broadcast network (Od. 1.347-52):

\section{Poets are not responsible; Zeus, somehow, is responsible Who gives to bread-winning men, to each, what he wants. There is no reason to fault the singing of the Danaans' bad fate. People celebrate more the song which comes latest to the hearers.}

When this little speech is over, Homer describes it while mentioning Penelope's reaction to it (1.361): "Marvelling she went back to the house/ for she put her son's prudent muthos in her heart." With this one touch, Homer characterizes the speaker Telemachus as an important rhetorician and a power in the house. The next speech by Telemachus reinforces the sense we get of his increasing power. Now that Athena has put strength in his spirit, as she promised, Telemachus can speak with a muthos, an authoritative utterance. At 1.367 Homer frames Telemachus' speech to the suitors saying "Telemachus the prudent began the muthoi." The topic of this public rhetoric actually focuses on a further muthos, as Telemachus says that tomorrow all will sit in assembly; at that time, he will make another speech (muthos ) "telling you off without regret" (1.373). Once again, a sense of the formulaic nature of Homeric art can lead us to larger conclusions here. For the phrase just translated, muthon apêlegeôs apoeipô, is found only one other place in all Homer. Achilles introduces his magnificent speech to the Embassy in Iliad 9 with these words (9.309). Rather than seeing this as a borrowing by the Odyssey poet from the Iliad, it makes more sense to say that both occurences of this half-line expression shed light on one another. This is the language of a young hero making a crucial pronouncement to an audience that wants him to do something else. We may recall that there are other resemblances as well between Achilles and Telemachus. In the speech in Book 2 that Telemachus forecasts here he will end up throwing a sceptre to the ground, just as Achilles does in Iliad 1. Again, characterization happens by means of slight differences between otherwise similar scenes. For Telemachus on throwing the sceptre bursts into tears; Achilles precedes his gesture with an imagepacked speech, but never cries. We might wonder whether the gesture is itself a stock one in archaic rhetoric. Perhaps it is planned by Telemachus, or even resembles the art of Homer in being both spontaneous and yet formulaic. At any

44. Martin (1989) 1-42. 
event, it punctuates and sets off Telemachus' speaking ability, the art that Homer has made us focus on by calling it muthos.

The third category of the technique of characterizing Telemachus within this medium of oral-formulaic poetry has to do with the rhetoric of his actual speeches. To examine even a single speech of one character takes a long time because one finds that every word has significant patterning attached to it, formulaic uses that could remind an audience of a number of associations. ${ }^{45}$ One example from the speech just cited will suffice to show how what one can call "speech type-scenes" help us understand a character. Just as we see more meaning in an arming scene or a feasting scene by comparing it with all the other instances of the type-scene, so too we can learn by examining repeated speech strategies that depend on the same sort of utterances. One can compare, for example, speeches that tell someone to do something or prayers or insults. Of course, the patterning in these genres can come from actual sociolinguistic use as much as from poetry. Homer tends to stylize strategies that we can note in the rhetoric of everyday life. ${ }^{46}$ When we hear someone utter the formulaic phrase words, "Let me handle this," we begin to construct the character of the speaker (e.g., s/he is the take charge sort) and evaluate the appropriateness of the utterance to the situation at hand. A similar opportunity for imagining character arises at $O d$. 1.358-59: Telemachus concludes his speech to Penelope by saying "go back to your quarters and do your own work and tell the maids to do theirs; big talk (muthos) will be a care to men, to all of them, especially me. For the power in the house belongs to this one." His words sound like those of an authoritative character, or one who strives to be. Yet when we compare this strategy of speaking with its occurrence in two other places, it appears that Telemachus is less the big man than he seems; or at least the issue is more complicated. At Od. 11.352-53, Alkinoos, the king of the Phaeacians, asserts that the arrangement of Odysseus' trip home will be his doing: "the send-off (pompê) will be a care to men, to all of them, especially me. For the power in the dêmos belongs to this one."

But why does he feel compelled to say this? Because his wife Arete has anticipated his utterance just before this, when she elicits even more gifts from the Phaeacians (11.336-41) by reminding them of their wealth and the guest's needs. It takes the intervention of an old retainer, Ekheneos, to readjust protocol. Arete does not speak authoritatively (mutheitai) off the mark, he says (11.34445), but Alkinoos is in charge here; at this point the king asserts his power. Given what we know about the Phaeacians from Books 6 through 8, we can say that Arete is in fact the power on this island; Nausicaa, the princess, has pointedly told Odysseus to bypass the jovial but ineffectual king and go straight to Arete when he wants to beg his way home (6.310-12). This means that, in context, the formulaic speech strategy " $X$ will be a care to me: I have the power" has overtones of being attached to one who is in fact still powerless. We can read this

45. Martin (1989) 167-205.

46. Martin (1989) 43-88. 
association as well in the most famous occurrence of this speaking strategy, at Il. 6. 490-93. Hector has ended his tender meeting with Andromache, who has tried to restrain him from reentering the fight on the field. "Go home; war (polemos) will be a care to men, especially me," he concludes. He cannot say "for I have the power" since technically Priam is still in charge, it seems, so the line ends instead "who (the men) have been born in Troy." If we read these words with his previous statement in mind-" no one can escape his fate" (6.488)-we hear not an assertion of actual authority but once more a more desperate attempt to wrest some power from position, precisely when the speaker knows he does not have the authority. Alkinoos and Hector are both upstaged; coming back to Odyssey 1, we can now expect that a traditional audience familiar with this speaking mode would hear irony in Telemachus' words. He thinks he can handle the situation on Ithaca, but he still has a lot to learn.

The fourth feature that effects characterization admittedly occurs in any narrative fiction. However, the precise use of this feature, which has been called narrative focalization, as we see it in the Odyssey emerges from the particular setting of oral-performance poetry. ${ }^{47}$ Focalization has to do with the way in which information is selected and channelled from the viewpoint of the author, character, or characters who implicitly "see" (as distinguished from narrate) the action. An internal focalizer is a figure within the tale whose privileged" viewpoint determines the flow of the narrative. With the constraints of focalization in mind, we might notice now that our Odyssey opens with a conspicuous gap when it comes to the situation on Ithaca.

The only hint that there is anything untoward happening on the home island comes just after the proem when Odysseus' homecoming is alluded to (1.18):

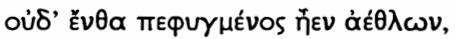

Not even there had he escaped contests.

A bit further on, the description of Odysseus that Zeus gives early in Book 1 is an apt example of how the suitor problem on Ithaca is elided (1.65-67):

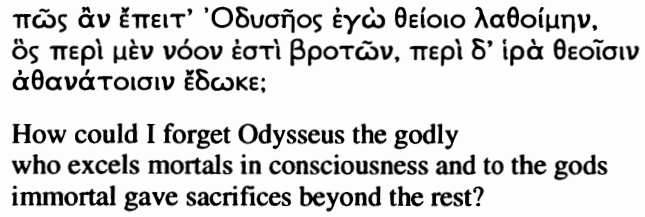

The only hint of what is happening on Ithaca then comes in Athena's words to Zeus at lines 1.88-91:

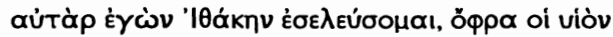

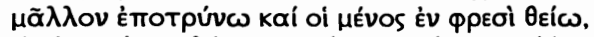

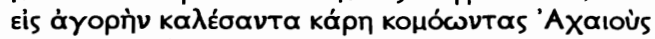

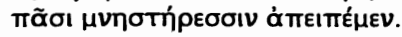




\author{
But I shall go to Ithaca, so that I might rouse \\ His son and place menos in his heart \\ So that once he has called the long-haired Achaeans to assembly \\ He might order away all the suitors.
}

Athena introduces the mention of the suitors as if who they are and whom they are wooing were already well known. But in fact there has been absolutely no mention of mnêstêres up to this point. It is a discourse universal that one needs to know certain things in a narrative; first-mentions are crucial; narrative figures are not simply intruded without identification. What happens in the Odyssey is different from the expected convention of a well-constructed narrative opening for some artful reasons.

First, this narrative gap can be explained if we assume the audience knows the story of Odysseus through a number of versions, which is to say, if we assume a traditional oral-performance audience. They know who the suitors are even if we, the uninitiated readers, do not. Let me tease out the implications of this point. The shape of the narrative makes us imagine an audience that has heard the story before. But this goes against precisely the thing that Telemachus has identified as the key quality of a poetic narrative--its novelty. This remark was earlier in this analysis deemed "ironic." We could get around this awkward disagreement over the art of narrative, the difference between Homer vs. Telemachus, by saying that Telemachus is referring to the style of a narrative; but it is clear from the language of his speech at 1.336-44 that he is thinking about information content, poetry as news. He says people like the "newest" story; but the Odyssey itself, at least the part about suitors wooing Penelope, has to be an old story. In fact, as many have pointed out, the themes of the Odyssey make it look like a very old story indeed. ${ }^{48}$ After all, it shares motifs with a number of earlier ancient Near Eastern texts, especially the Gilgamesh epic. The most one can say at this stage is that there is a tension between the professed ideology of poetry that we see displayed in Telemachus' speech, and the compositional realities of the Odyssey. Or perhaps Telemachus, not yet being fully perceptive, does not know how poetry works; in the words of Piero Pucci, he is an "intoxicated reader" who values poetry on the basis of its power to charm. ${ }^{49}$ If Homer is silently showing us a young man with a bad head for literary criticism, then we have yet another touch of characterization that seems to fit the earlier picture of Telemachus as a learner. If, on the other hand, we read Telemachus as claiming that the best songs are completely new compositions, in a larger sense, then what he says is in perfect accord with what Lord and others have taught us about oral performance: every composition, no matter how old its themes and expressions, is a brand new work because it has a different shape based on the ever-changing relation between audience and performer. 50

In the "gap" just mentioned - the failure to introduce the suitors properly as a plot element-there is a further point relevant to characterization. If we look

48. See Foley (1987).

49. Pucci (1987) 201-08.

50. Lord (1960) passim, esp. 148-57. 
at what is happening here in terms of literary pragmatics, it appears that only one person in the narrative can be assumed to know about the suitors without introduction. Only one character is keyed in to the action on Ithaca enough that he can recognize who the suitors and their object are without being told. That character is of course Telemachus. In other words, the Odyssey as it starts is filtered to us through the eyes and ears of Telemachus, even before we begin the adventures of the young hero within the Telemachy. In narratological terms, he is the internal focalizer of the action: although he is not the narrator, we still see the action as he would see it. This is the most important although least obvious device for Homer's characterization of Telemachus. Not only is he godlike in eidos, an apprentice at learning muthos skills, and still somewhat in his mother's control in Book 1. He is like us, and we are like him, both in the position of audience for the heroic past. It has been noticed before that just as Telemachus only now learns about his father, so too we must pick up hints through the journey of Telemachus to gain an understanding of Odysseus. ${ }^{51}$ But I want to stress how firmly embedded this conditioning is in terms of the narrative's point of view. If we take this focalization process seriously, we can explain also why Eumaeus the swineherd is the only person addressed consistently in the second person by the poet: "O my swineherd" (14.165, etc.). He has been, after all, the closest male to Telemachus on Ithaca. Even the suitors are represented as thinking that if Telemachus is missing from town he must be out at the swineherd's hut (4.640). The use of the second-person address to Patroklos in the Iliad can be explained as the reflex of focalization through Achilles, which in turn is attested by the dictional overlaps between the Iliad poet and his main hero. ${ }^{52}$ So too here the use of second-person address goes hand in hand with Telemachus as focalizer. He is the person within the narrative most likely to address Eumaeus this way, in ordinary discourse; his point of view then gets extended to the telling of the narrative itself, as the poet and the focalizer of narration often coincide.

I want to conclude by returning to the "last hero song" of my title and speculating about what it means in terms of the Odyssey's overall thematics to have Telemachus, the gateway to this poem, characterized as he is in the formulaic ways I have shown. We receive the poem filtered through an internal audience who desires and listens to Odysseus' story. This audience of one, Telemachus, has his own small adventure story, the goal of which is to gain fame as well as information (cf. 1.94-95). But we cannot fail to notice that Telemachus at the end of the poem is back in a subordinate position. As in a pedimental sculpture, he flanks his father along with his grandfather Laertes in Book 24. Even if he has grown, he is still not the power in the house. Furthermore, even by the end of the poem, Telemachus has not filled the role of his father in one crucial respect: while pepnumenos, he is not polumêtis. Odysseus descends from tricksters, is a trickster in this poem, and continues to be one in the long tradition 
of Western literature. ${ }^{53}$ His son never has the opportunity: the trickster's only son has failed to follow the tradition.

If we join this observation to a series of other oddities about the Odysseyfor example, its ethical stance-it becomes clearer that the poem itself speaks of the end of a tradition. ${ }^{54}$ One can see this most clearly in the underworld scenes of Book 24, a send-off to the entire heroic world of Troy. The heroes are all gone. In the beginning of the poem the Telemachy exists, I think, because the Odyssey dwells thereby on the problem of its own transmission. How can oral poets compose if the audience is made up of young men like Telemachus? Can stories change the hearer? Can Telemachus be educated? Yes, the Odyssey seems to say tentatively; but then Telemachus becomes different and the old world that made the stories passes away with his father's last voyage outward. ${ }^{55}$ To a traditional audience, such as we can reconstruct by extensive reference to comparative folk materials, the omission of a trickster's career or heroic story for Telemachus must be extremely significant; these gaps say something important about the story. By preposing the Telemachy and thus foregrounding the whole problem of father-son relations, the poet of the Odyssey made a conscious attempt to perform a poem about the end of tradition. Moreover, to speak of the end of heroic tradition, tailing out with the quite ordinary Telemachus, is also to comment on the end of a poetic tradition, epic verse as practiced by the poet of the Odyssey itself, for the two are symbiotic. The point is perhaps not as clear for modern audiences. Yet what we know of the sociology of oral performance transmission can show that the usual mode of a singer's development depends on learning traditional epic songs from his (or her) father. ${ }^{56}$ It becomes more significant in this specific regard that the Odyssey sets up, then dashes, audience expectations about the character of the hero's son. We never see Telemachus perform; he never tells his story; our attention is shifted from son to father, who then outdoes even the poet Homer (so it seems) by holding audience attention for the space of four books narrated by himself. Rather than being an adventure story with an extra bit tacked on the beginning (as Analysts view it) or a meditation on ambiguity, disguise, language and the Text (as modern Unitarians would construe it), the Odyssey, thus, in this metapoetic reading, is a much more context-bound and specific performance by a poet concerned about the very social conditions that might (but eventually, in fact, failed to) allow epic art to grow. Telemachus is the emblem of that ending.

53. On Odysseus as trickster, see Russo (forthcoming). I thank Prof. Russo for letting me see the page proofs of this article.

54. On the problems of Odyssean ethics, see the convincing arguments (in favor of reading the poem partly as ancient ideological justification for domestic violence) of Nagler (1990).

55. In placing the theme of father-son relations in this framework, I seek to explore yet another layer of the theme recently discussed, in its relation to Hesiodic ideology, by Arrighetti (1991).

56. Cf. Zygas (1974) which documents the shrinking of the performers' knowledge of epic over four generations. See also Lord (1960) 22-26 on learning epic songs from the father in Serbo-Croatian traditions. 